\title{
Evidence of Structural Facts Inferred from Aeromagnetic Data Analysis over the Guider-Maroua Area (Northern Cameroon)
}

\author{
Jean Daniel Ngoh ${ }^{1 *}$, Théophile Ndougsa Mbarga ${ }^{1,2 *}$, Stéphane Patrick Assembe ${ }^{1}$, Arsène Meying ${ }^{3}$, \\ Olivier Ulrich Owono', Tabod Charles Tabod ${ }^{1,4}$
}

\author{
${ }^{1}$ Postgraduate School of Science, Technology and Geosciences, University of Yaoundé I, Yaoundé, Cameroon \\ ${ }^{2}$ Department of Physics, Advanced Teachers' Training College, University of Yaoundé I, Yaoundé, Cameroon \\ ${ }^{3}$ School of Geology and Mining Engineering, University of Ngaoundéré, Meiganga, Cameroon \\ ${ }^{4}$ Faculty of Science, University of Bamenda, Bambili, Cameroon \\ Email: ${ }^{* j d n g o h @ g m a i l . c o m, ~}{ }^{\star}$ theopndougsa@gmail.com
}

How to cite this paper: Ngoh, J.D., Mbarga, T.N., Assembe, S.P., Meying, A., Owono, O.U. and Tabod, T.C. (2017) Evidence of Structural Facts Inferred from Aeromagnetic Data Analysis over the GuiderMaroua Area (Northern Cameroon). International Journal of Geosciences, 8, 781-800. https://doi.org/10.4236/ijg.2017.86044

Received: April 12, 2017

Accepted: June 16, 2017

Published: June 19, 2017

Copyright () 2017 by authors and Scientific Research Publishing Inc. This work is licensed under the Creative Commons Attribution International License (CC BY 4.0).

http://creativecommons.org/licenses/by/4.0/

\begin{abstract}
In this study, we performed some filters to highlight geological structures and/or features which are found in the igneous rocks, between the latitudes $9^{\circ} 45^{\prime} \mathrm{N}$ to $10^{\circ} 45^{\prime} \mathrm{N}$ and longitudes $13^{\circ} 15^{\prime} \mathrm{E}$ to $14^{\circ} 30^{\prime} \mathrm{E}$. The application of the first vertical derivative (FVD) and the horizontal gradient magnitude (HGM) on a total magnetic data over the study area has led to put in evidence: 1) geological features as geological boundaries, faults, dykes, folds on the FVD map; 2) abundant aeromagnetic lineaments probably fractures, dykes and contacts, exhibit a conjugate relationship suggesting a near NE and NW tectonic trends; 3) existence of a possible prominent near E-W compression, characterized by a possible dextral displacement of geological formations by the shear movements; 4) and the magnetic signature of the country rocks.
\end{abstract}

\section{Keywords}

Magnetic Gradient, Reduction to the Equator, First Vertical Derivative, Horizontal Gradient Magnitude, Lineament, Tectonic Trend

\section{Introduction}

In principle, magnetic surveying is similar to gravity i.e. it deals with potential fields. But, there are some fundamental differences. Magnetic measurements are simple to make and reduce, but very complicated to understand and interpret [1]. Magnetic surveying is the oldest method of geophysical prospecting, but has been relegated to a method of minor importance because of the advent of seismic reflection surveying in the last few decades. The great problem involved in 
interpreting magnetic anomalies greatly limits their use [1]. Magnetic survey is mainly used to detect igneous rocks, folds and faults, delineate magnetic lineaments and, highlight their relationships to tectonic fabric in geological studies and mineral exploration [2]. The target is the depth to basement (i.e. thicknesses of sedimentary sequences, igneous bodies). Recently, there has been resurgence in interest in the magnetic surveying because of the advent of extremely high resolution surveys that can reveal structures in, sedimentary sequences [1]. Based on that, many types of images can be produced from magnetic data sets. Different images enhance different features that enable to make full use of the data [3]. Conventionally, many filters can be used to improve magnetic data interpretation. Among these are the first vertical derivative and horizontal gradient magnitude filters.

The area under study (Figure 1 ) is bounded by north latitudes $09^{\circ} 45^{\prime}-10^{\circ} 45^{\prime}$ and east longitudes $13^{\circ} 15^{\prime}-14^{\circ} 30^{\prime}$ and located in the northern Cameroon. The geological formations encountered are linked to the Phanerozoic sedimentary basins, the Pan-African metasediments, the Neoproterozoic granitoids and Neoproterozoic schist-orthogneisses [4] [5].

Since 1960, many geophysical studies have been carried out in the northern Cameroon. The first aeromagnetic maps were compiled by [6] in the aim to draw the mining and geological maps of the Country. The gravity studies done by [7] and [8], have shown that in the region, there are two major gravity anomaly families with the NE-SW negative anomaly which may coincide with a Quaternary sedimentary cover. The gravity data from [9] have been used later by [10] to infer the structure of the Goulfey-Tourba basin. Recently, other geophysical work realised by [11] shown the inter-locked Logone Birni Basin (LBB) tectonic and geophysical models. [11] results have confirmed former basic knowledge on the tectonic and geophysical models of the West and Central African Rift System, but also offer new insights on the peculiar tectonic conditions in the LBB. Despite all these previous studies, the geological knowledge of northern Cameroon specifically, the studied area has to be improved.

The purpose of this paper is to use first vertical derivative (FVD) and horizontal gradient magnitude (HGM) filters on the aeromagnetic data in the northern Cameroon, in order to identify the main magnetic features (buried faults, folds, intrusions, etc.) and interpret them within a regional geological context. Qualitative analyses of various aeromagnetic maps from the above filtering techniques will be playing a key role in the determination of the structure of the subsurface.

\section{Geological Setting of the Study Area}

The lithology of the study area (Figure 2) is made up of: 1) Neoproterozoic medium- to high-grade schists and gneisses of the Poli-Lere group that were formed in a magmatic arc context [12]; 2) Pan-African pre-, syn- and post-tectonic calcalkaline granitoids [4] [13]; 3) post-tectonic alkaline granitoids comprising mafic and felsic dykes cross-cut by intrusive granites and syenites; followed by the formation of 4) several basins made up of unmetamorphosed sediments and volcanic rocks [14] [15]. Isotope dating indicates that most of the gneissic and granitic 
rocks of this domain are Neoproterozoic in age with minor Palaeoproterozoic contribution, contrasting with the abundant Palaeoproterozoic formations that characterize the Adamawa-Yade domain to the south of the study area [16].

Structurally, two deformation phases (Figure 2) followed by late-orogenic shear zone are recorded in the NW-Cameroon domain, particularly in the Poli area [14] [17] [18]. The first deformation is characterized by a flat-lying foliation associated with isoclinal folds. Stretching lineation's are locally well preserved and the second deformation is marked by vertical and NNE-trending foliations, and by tight and upright folds [19]. In the Poli area, synmigmatitic N80-N110 senestral shear zones accompanied this second event [20].

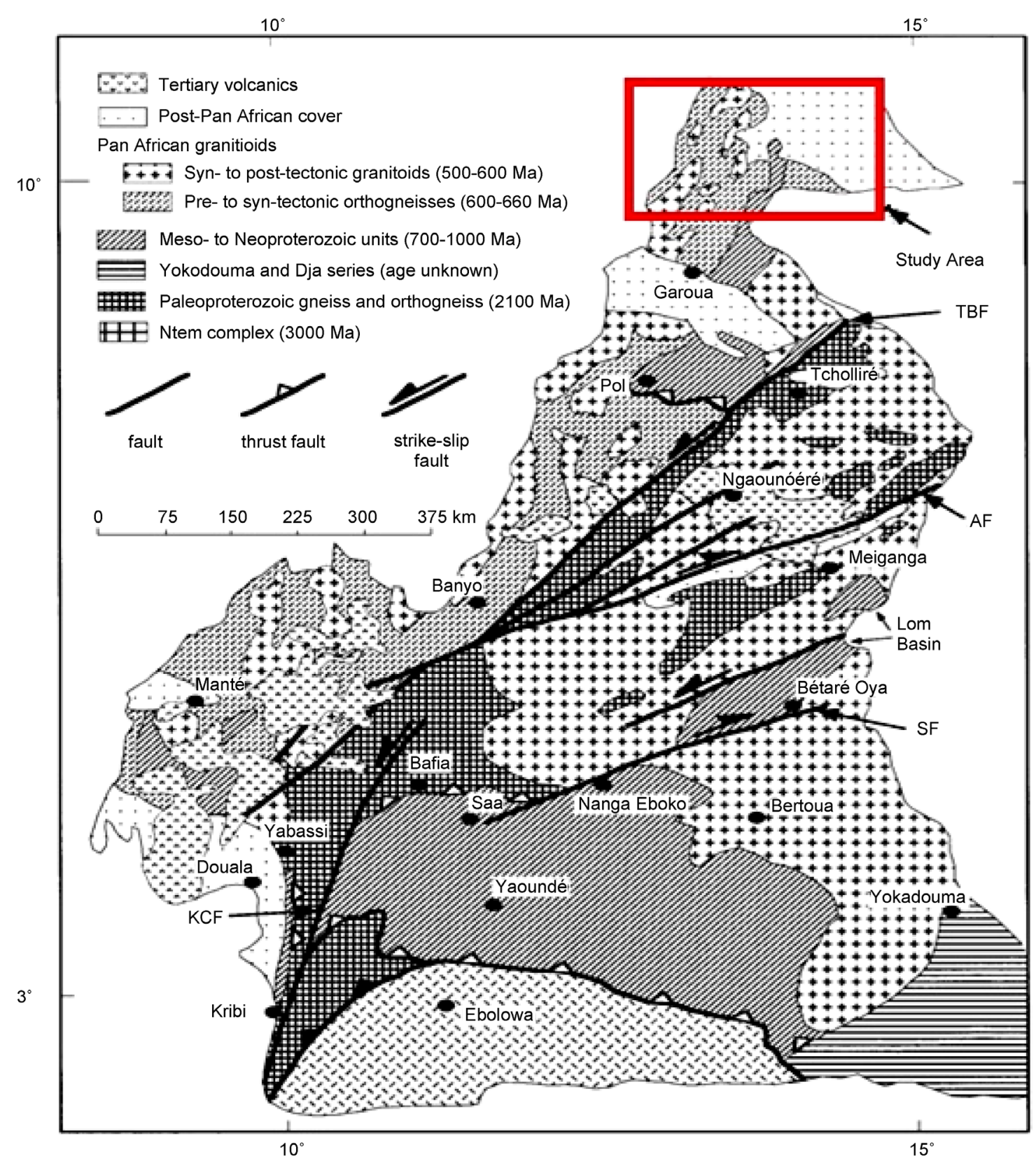

Figure 1. Location map of the study area with the some regional major structure: $\mathrm{TF}=\mathrm{Tcholliré}$ Fault, $\mathrm{AF}=$ Adamawa Fault, SF = Sanaga Fault [4]. 


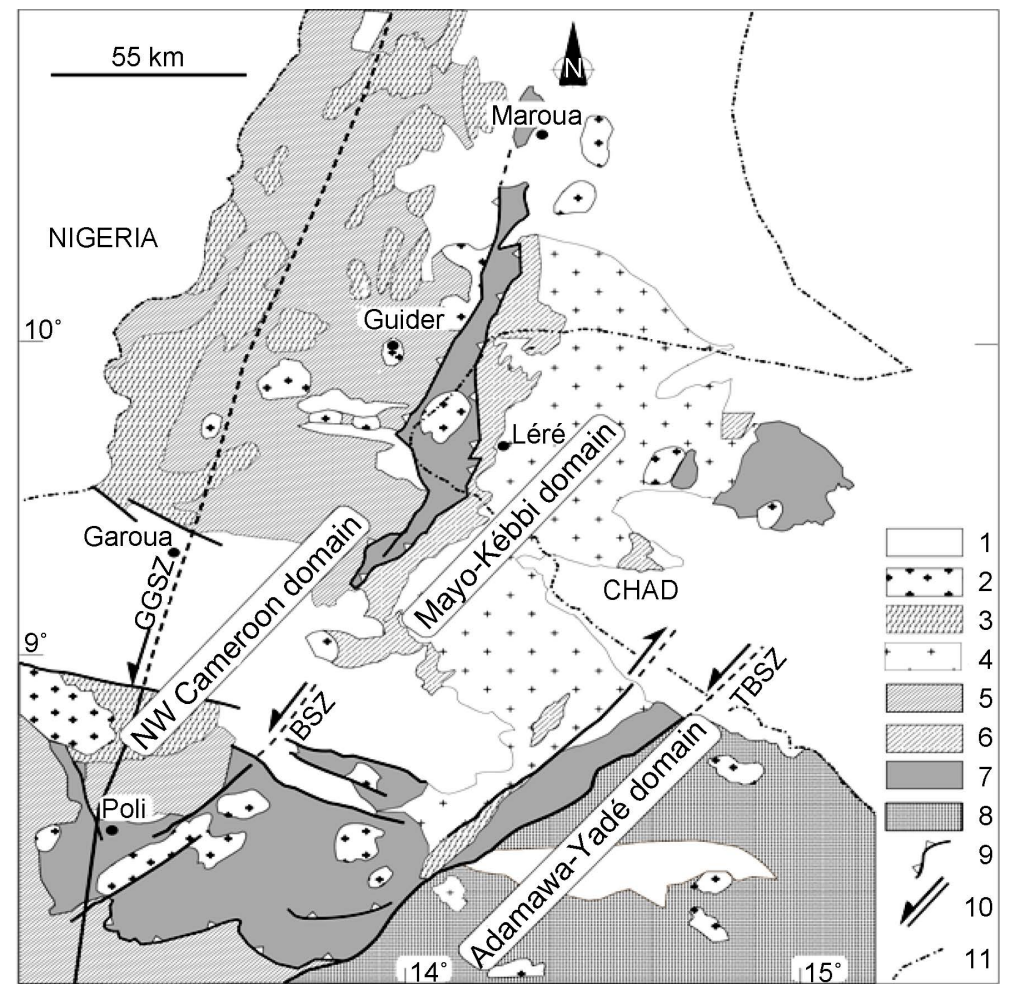

Figure 2. Simplified geologic map of the study area [13]: (1) Post-Pan-African sediments; (2) Late to post-tectonic Pan-African granitoids; (3) Syntectonic granite; (4) Mayo-Kebbi batholith: tonalite, trondhjemite and granodiorite; (5) medium- to high-grade gneisses of the NW-Cameroon domain; (6) Mafic to intermediate complex of the Mayo-Kebbi domain (metadiorite and gabbrodiorite) and amphibolite; (7) Neoproterozoic low- to medium-grade volcano sedimentary sequences of the Poli-Léré Group; (8) Remobilized Palaeoproterozoic Adamawa-Yadé domain; (9) Thrust front; (10) Strike slip fault: TBSZ= Tcholliré-Banyo shear zone; GGSZ = Godé-Gormaya shear zone; (11) State border.

\section{Materials and Methods}

\subsection{Aeromagnetic Data}

The key component of this study involved image enhancement of existing aeromagnetic data sets acquired by the company SURVAIR (contractor) for the CIDA (client) in 1970. Aeromagnetic surveys were flown with a flight height of $235 \mathrm{~m}$ and a nominal flight line spacing of $750 \mathrm{~m}$ in direction $\mathrm{N} 135^{\circ}$. After correction of the measurements for the temporal variations of the magnetic field, the total magnetic intensity (TMI) anomaly was deduced by subtracting the theoretical geomagnetic field or IRGF (International Geomagnetic Reference Field) at each station. The TMI anomaly data were then upward continued to a height of a mean clearance of $2 \mathrm{~km}$ before they were merged into a unified digital grid. The reduction to the equator method is applied. In this case, the magnetic field and magnetization will be horizontal as most of the magnetized sources [21] [22]. The Geosoft package software v8.0 was used to reduce the field to equator (RTE) transformation of an anomaly in the Fourier domain. The inclination and declination angles of the ambient field were taken as $-0.98^{\circ}$ and $-3.95^{\circ}$, at the date of January 1970 according to IGRF. 


\subsection{Methods}

Several filtering techniques can be performed in the frequency domain. In this work, two main advanced techniques are used to analyse the magnetic data as a guide for structural interpretation: the first vertical derivative (FVD) and the horizontal gradient magnitude (HGM methods) [23] [24] [25]. These methods have proven to be efficient tools to map the location of magnetic structures such as faults and contacts [21] [22].

\subsubsection{First Vertical Derivative (FVD)}

The vertical gradient operator is applied often to magnetic data to sharpen the edges of anomalies and other features [6] [22] [26]. It is more responsible to local influences than broad or regional effects and therefore, tends to give sharper picture than the map of the total magnetic field. Thus, the smaller anomalies are more readily apparent in area of strong regional disturbances [22]. The algorithm is given by [27] as follows:

$$
M(x, y)=M(x, y) \sqrt{\left(\left(x^{2}+y^{2}\right) / n\right)^{n}}
$$

where $n$ is the order of the derivative.

\subsubsection{Horizontal Gradient Magnitude (HGM)}

Horizontal gradient is a simple approach to locate linear structures such as contacts and faults from potential field data. For magnetic field $M(x, y)$, the horizontal gradient magnitude $\operatorname{HGM}(x, y)$ is given by [23] [24]:

$$
\operatorname{HGM}(x, y)=\sqrt{\left(\frac{\partial M}{\partial x}\right)^{2}+\left(\frac{\partial M}{\partial y}\right)^{2}}
$$

This function peak over magnetic contacts under certain assumptions: 1) the magnetic field and source magnetization are vertical, 2) the contact is vertical and 3) the sources are thick [28]. Violation of the first two assumption leads to shift of the peaks away from the contact location. Violation of the third assumption leads to secondary peaks parallel to the contacts. In order to partially satisfy the first two assumptions, the method was applied to the regional component of the reduced to the equator magnetic data. Once the field has been reduced to the equator, the regional magnetic field will be horizontal and most of the source magnetizations will be horizontal. Crests in the horizontal gradient magnitude grid can be located by passing a small 3' by 3' window over the HGM grid and searching for maxima [25]. When these assumptions are satisfied, the method is effective in detecting lineaments that may correspond to basement faults and contacts. Moreover, the method is less susceptible to noise in the data, because it only requires calculation of the two first-order horizontal derivatives of the magnetic field.

Because the FVD and HGM methods require the calculation of the first order derivatives of the magnetic field, they are susceptible to increase noise in the data. In this paper, the two methods are applied to the upward continued data in order to reduce the noise and improve the signal-to-noise ratio.

The preparation of data set for the current study consisted in: 1) subtracting the IGRF from the total field data, to obtain the total magnetic intensity (TMI) 
anomaly field; 2) applying the upward continuation at $2 \mathrm{~km}$ height (to the TMI map) to improve a signal to noise ratio; 3 ) applying the reduction to the magnetic equator (RTE) transformation (leading to RTE map) in order to move magnetic anomalies above their causative sources [29] [30]. The processing is done on the Oasis montaj 8.0 platform and the IGRF being considered on January 1 st, 1970 (providing an inclination $\mathrm{I}=-0.98^{\circ}$ and a declination $\mathrm{D}=-3.95^{\circ}$ ) over the study area.

\section{Results and Analysis}

Generally, qualitative interpretation is done by visual inspection of maps, while the quantitative interpretation is performed using analytical methods. In this work, two main techniques were applied (for qualitative interpretation) as an aid to structural interpretation or mapping, from airborne magnetic data for the detection and location of subsurface structures or magnetic source edges.

\subsection{The Total Magnetic Intensity Anomaly Reduced to the Equator (RTE) Map}

The Total magnetic intensity anomaly reduced to equator (RTE) map (Figure 3)

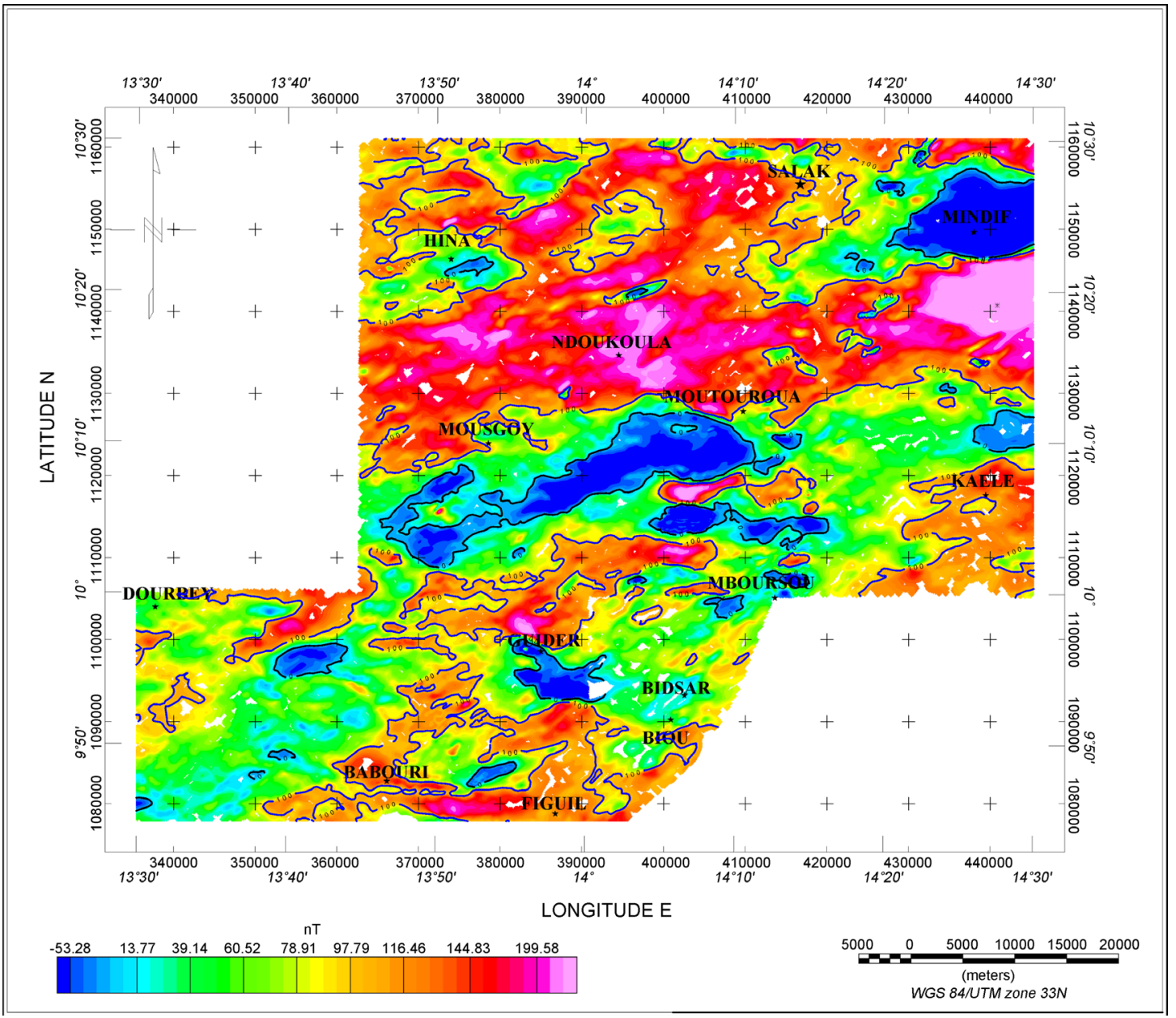

Figure 3. Total magnetic intensity reduced to equator map. 
is broadly characterized by anomaly values ranging from about $-83 \mathrm{nT}$ to 300 $\mathrm{nT}$. The RTE map exhibits some different types of positive (magenta and red colours) and negative (light and dark blue colours) magnetic anomalies. It reveals prominent negative features with circular and elongated shapes, distributed at the northern, central part of the study area, along with small sized ones in the southern parts.

The northern part of the study area exhibits a major positive high amplitude magnetic anomaly, in positive background (green to yellow colour) covering the area from west to east, with irregular shapes. Some isolated, circular and elongated negative magnetic anomalies occur within this northern part. The vast negative magnetic anomaly located at Mindif reaches $-83 \mathrm{nT}$ is directly bounded by steep positive gradients in the south. The observed positive magnetic anomalies at Mindif neighbourhoods may be due to the presence of some shallow and/or deep sources.

The central part of the area under study is located between Moutouroua and Mboursou latitudes. Herein, some elliptic magnetic anomalies (either positive or negative) are disseminated throughout in a positive background (green). A vast negative magnetic anomaly striking ENE-WSW to E-W covers the middle of this area part. An isolated and elongated positive anomaly also located in the centre of the map, follows the E-W direction. These isolated circular and elongated positive (reddish) magnetic anomalies can be interpreted as intrusions of magnetic bodies through the basement.

The southern part, finally, located below the Mboursou latitude essentially, displays isolated magnetic highs and lows (Guider) within a positive background (green to yellow). This part is dominated by ENE-WSW to E-W foliation trend reported by magnetic patterns. Some positive anomalies are recorded north of Guider, and in Babouri-Figuil, while negative anomalies are recorded east of Dourbey and at Guider. Around Guider, there is a steep positive magnetic gradient, which could be due to surface structures effects.

The map shows three main types of magnetic anomalies: high (red to pink), moderate (green to yellow) or low (light-green to blue) amplitude anomalies. The high amplitude magnetic anomalies (red to pink) dominate the northern part of the study area, displaying a wide span south bounded by the MousgoyMoutouroua axis. Besides, several isolated and elongated high amplitude anomalies are located at Figuil, Babouri, near Kaele and Guider. The anomalies in the northern part may have been caused by deep sources. These anomalies exhibit patterns of E-W trends probably caused by the movements of Pan African formations. The low amplitude magnetic anomalies are elliptic and curveshaped. They occur at the centre of the study area, with some isolated occurrences at Mindif, Mboursou, Guider and south-east of Babouri. These anomalies may be due to rock formations constituted by very low susceptibility minerals, probably sedimentary formations or deposits. Therefore, the areas displaying these low magnetic anomalies can be assimilated to sedimentary zones (or basins). The moderate amplitude magnetic anomalies (greenish to yellow) cover the whole map. It is ascribed as corresponding to the magnetic background sig- 
nature which is assumed to characterise the country rocks.

A global look of the entire map (Figure 3 ) shows that there are negative magnetic anomalies observed at the north-eastern and the central part; these two anomalies could be considered as a unique anomaly domain split into two parts by a broad $\mathrm{E}-\mathrm{W}$ trend. This map also reveals some magnetic discontinuities or disruptions highlighted magnetic facies. The discontinuities or disruptions can be correlated to faults or folding, probably buried. In addition, step gradients observed between magnetic facies can represent contacts of different formations.

\subsection{The First Vertical Derivative (FVD) Map}

The first vertical derivative (FVD) operator is used for image enhancement. Applied to the RTE, it enables to highlight lineaments such as boundaries, faults or folding. The first vertical derivative (Figure 4) map shows many linear and circular magnetic features, allowing interpretation at a regional or a local scale. It is overall characterized by anomaly gradient values ranging from $-0.129 \mathrm{nT} / \mathrm{m}$ to

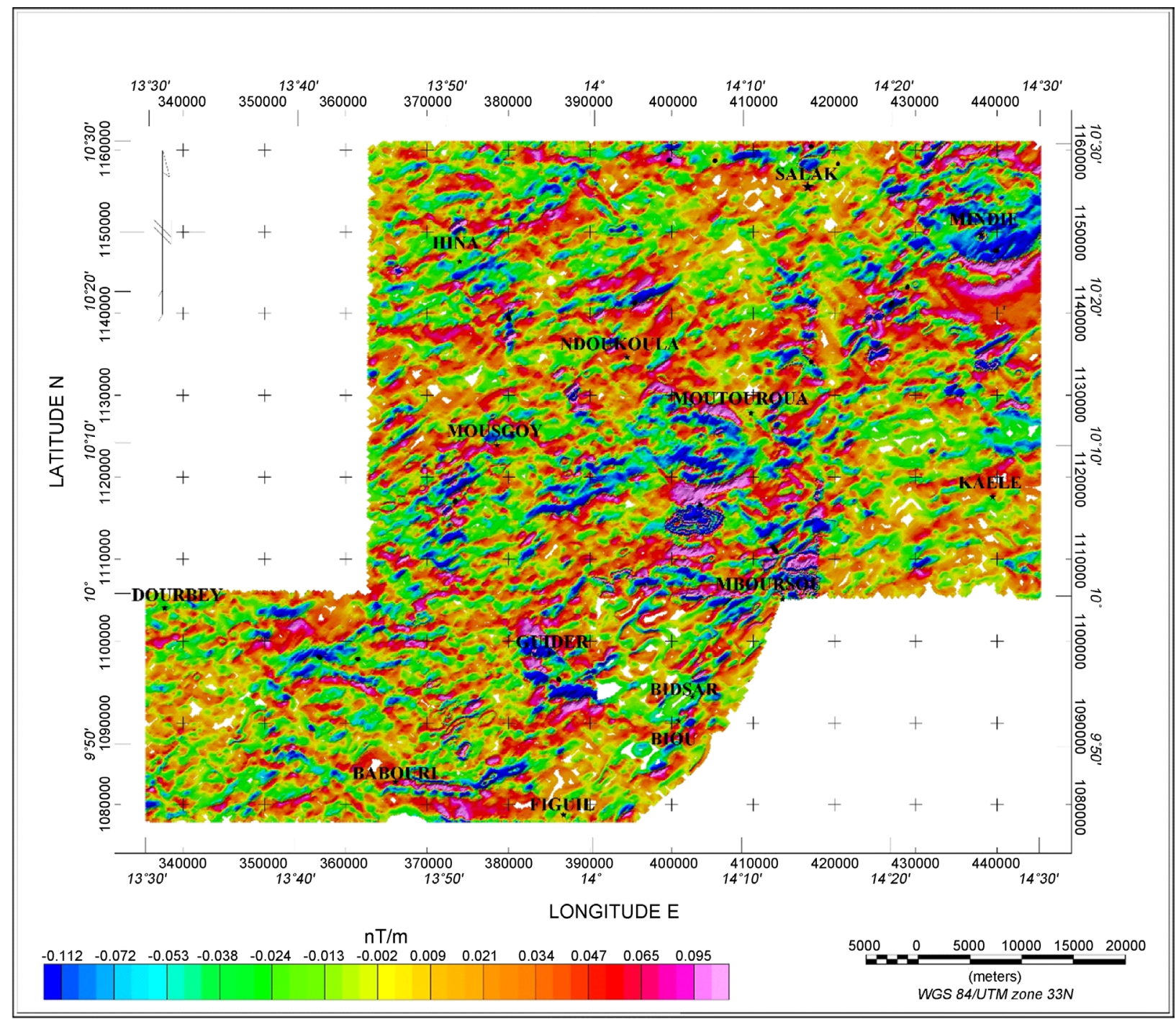

Figure 4. First vertical derivative of total magnetic intensity reduced to equator map. 
$0.077 \mathrm{nT} / \mathrm{m}$. Gradients are qualified respectively as high (pink-peak positive values), moderate (green) or low (blue-negative) depending on the magnitude. In the Mindif area, there is a prominent circular magnetic gradient with very low amplitude reaching $-0.129 \mathrm{nT} / \mathrm{m}$. As shown on RTE map (Figure 3), this prominent anomaly couldn't be only due to shallow structure but edges of this anomaly are emphasized, because the application of derivative filters tends to sharpen the edges of anomaly sources [22]. In addition, there are more isolated, linear prominent magnetic features identified on the currently enhanced magnetic data, which could be due to both shallow and deep sources. Several features termed as lineaments were identified on the FVD map and were interpreted as possible dykes, folds or faults and contacts or boundaries between formations. The highlighted lineaments are continuous or discontinuous, short or long. Some of the magnetic gradient anomalies arising from basement may be due to deep structural features. The trends of the above describe lineaments are NNE-SSW, ENE-WSW, WNW-ESE, NE-SW, NW-SE, N-S and E-W.

The geological boundaries (contact zone), folds, faults and shear zones are revealed by suddenly trending changes observed on the FVD map (Figure 4); they constitute principal weakness zones that affect the near subsurface and the basement as well. Important circular magnetic gradients observed at northeastern and central part of the map are insights of subsidence areas (graben) which appear to be bounded by igneous dykes, folds or faults. As shown on the RTE map (Figure 3), these probable grabens are aligned along the NE-SW or E-W axis.

On the basis of the available geological information, the sources of the magnetic low anomalies at Mindif and/or Hina, may correspond to Phanerozoic sedimentary basins. The entire study area is faulted and has several narrow magnetic features, with the NW and NE directions. More of them are fairly good correlated with its basement which is dominantly of Precambrian basement composed of granite and gneiss formations. Many geological features or discontinuities identified are possibly due to the uplift of the Precambrian bedrock, which is faulted or folded. Some of these shear zones are relics of basement tectonics and/or early Precambrian plate boundaries. Therefore, initial structural analysis of the first vertical derivative map indicated some prominent sets of faulting and structural trends in the study area with N-S, E-W, NW-SE and NE-SW directions. However these are distributed along the regional trends oriented NE-SW and NW-SE. So, the first vertical derivative mainly show several edges which may mark transition zones and could be due to the presence of: 1) boundaries between different geological or litho-structural formations; 2) faulted formations (due to buried faults which could be encountered in this area); 3) and intensely folded zones. On the basis of the intensity range, character and shape of the magnetic gradient responses, the FVD map (Figure 4) is essentially characterized by magnetic gradient high and low values on a moderate magnetic background (green to yellow), which characterize the magnetic signature of the country rocks. 


\subsection{The Horizontal Gradient Magnitude (HGM) Map}

The horizontal gradient filtering was performed in the frequency domain using the Fast Fourier Transform. The horizontal gradient magnitude (HGM) is computed as the magnitude of the sum of the squared X-horizontal and Y-horizontal derivatives. The horizontal gradient magnitude (HGM) map shown in Figure 5 presents magnetic features characterized by high gradient values within a moderate background (greenish). The amplitude value of the observed anomaly is variable and also his shape. The corresponding trends are mainly following the ENE-WSW and E-W directions. The HGM amplitudes peak is $0.140 \mathrm{nT} / \mathrm{m}$. Vast circular and elliptical anomalies at Mindif, Moutouroua, Mboursou and Guider are clearly visible. They are characterized by high amplitude gradients probably caused by intrusions or outcrops of magnetic bodies. These close-shaped anomalies may also correspond to faults that bound probably grabens or basins (e.g. in the Mindif and Babouri areas). Many thin high magnetic gradient anomalies are

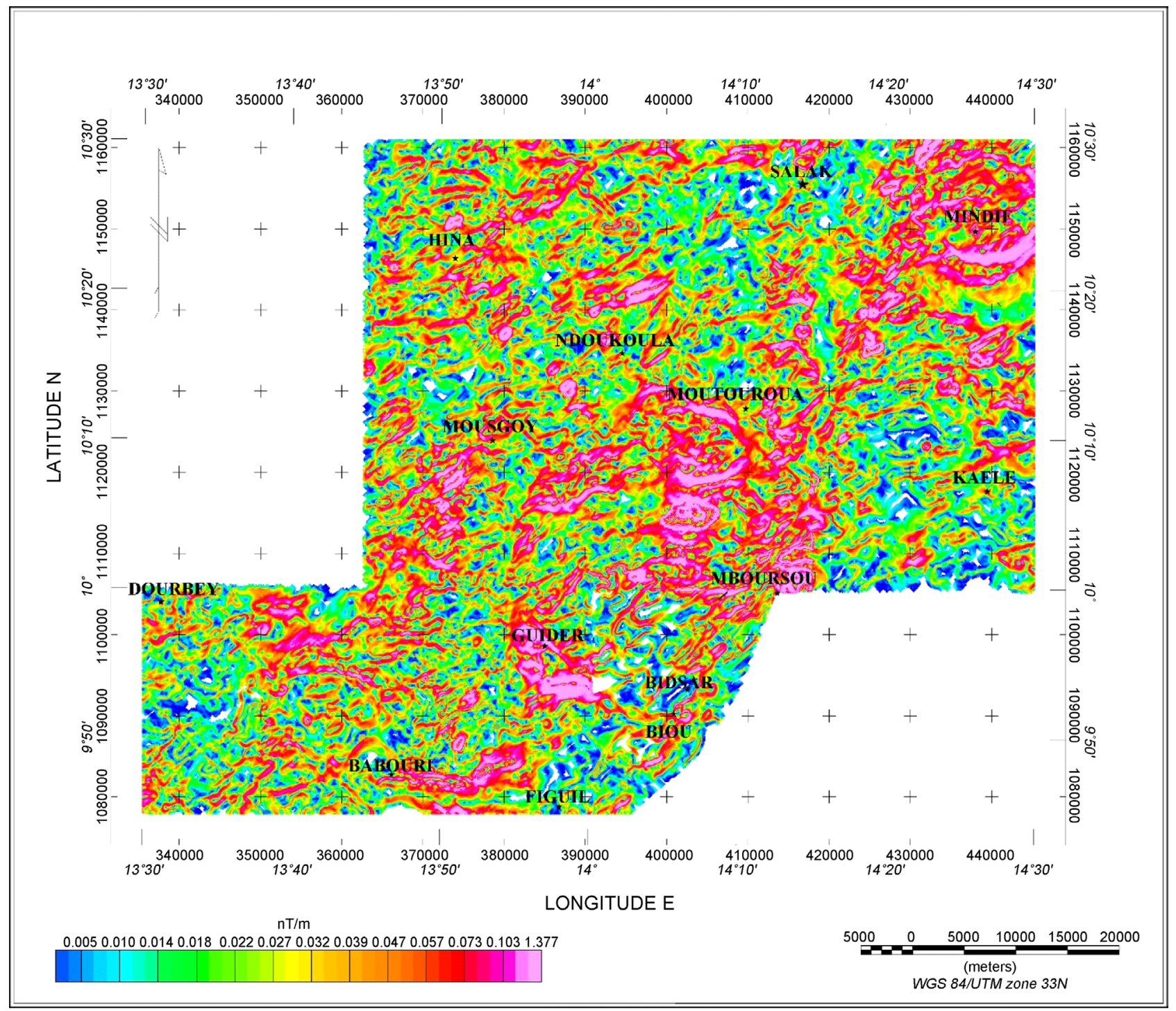

Figure 5. Horizontal gradient magnitude of residual magnetic anomalies map. 
also highlighted. They are either linear or curved and irregularly distributed over the study area. In some places, these magnetic features are splited or discontinued. Some of these thin anomalies delineate boundaries zones between different litho-structural units and/or evidence the presence of buried faults and/or dykes. Such magnetic linear features when stacked commonly represent major crustal shear zones and faults.

In order to clearly highlight the contacts direction shown on the HGM map, the maxima of the HGM has been computed using the [25]. The application of this technique to the horizontal gradient magnitude (HGM) map shows that the local maxima of the horizontal gradients form narrow lines above sudden changes of susceptibility [21] [22]. Figure 6 shows the concern map of HGM maxima. This map reveals structural features such as folds and faults affecting the basement. The different structural features were recognised by differences in the patterns (such as general orientation and arrangement) of faults inferred

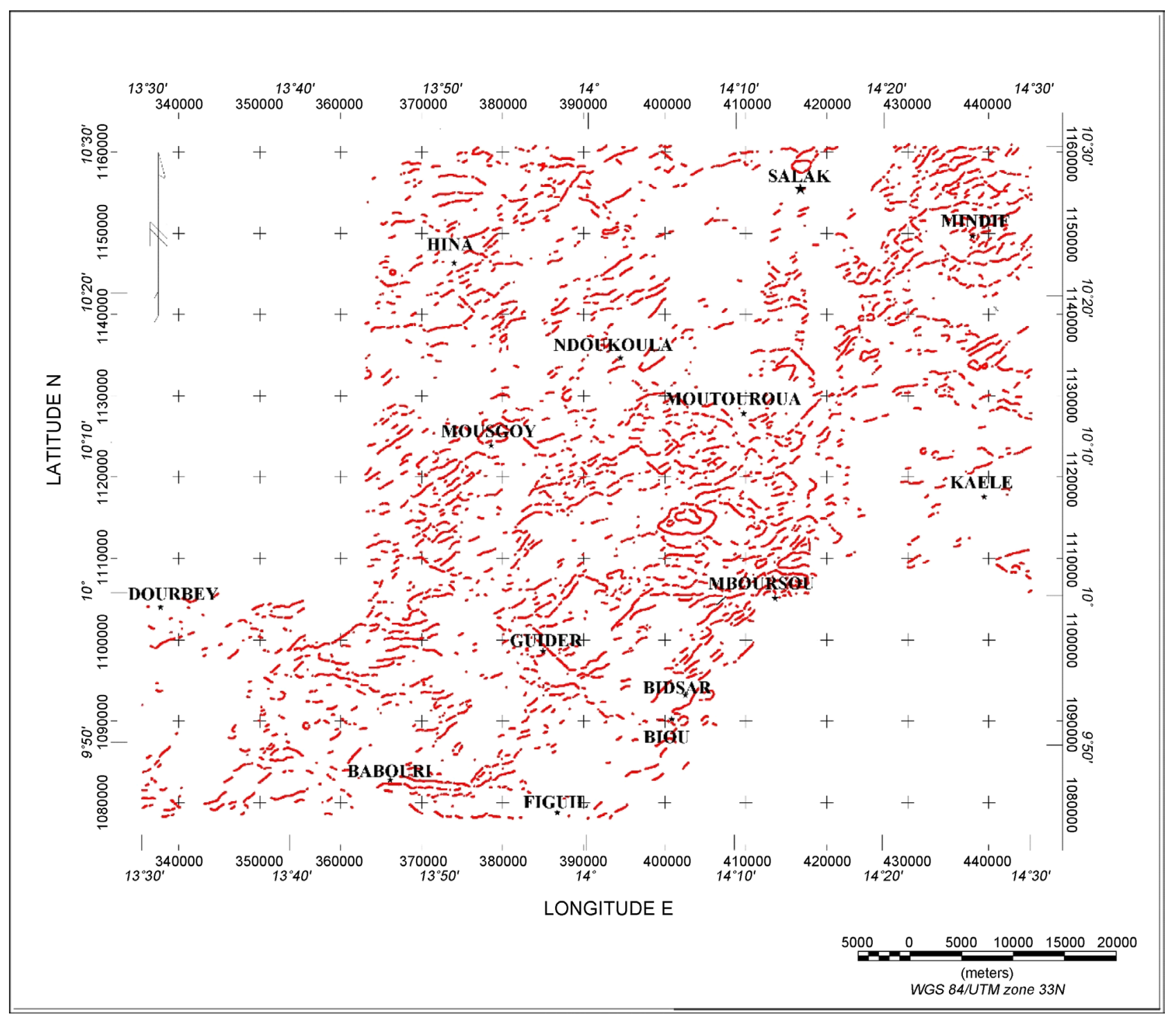

Figure 6. Local maxima of horizontal gradient magnitude map. 
from the current study. The lineaments from the whole map follow major ENE-WSW and E-W directions.

The horizontal gradient magnitude ridges were commonly used to clearly define the lineaments identified in the aeromagnetic data. In comparison with the previous map (Figure 4), a relative good correlation of some geological facts. The presence of circular or closed elongated magnetic anomalies may be due to deep geological features hidden by overburden formations. The abrupt terminations or changes in aeromagnetic anomaly character or the termination of horizontal gradient magnitude ridges along a linear edge, could also reveal the presence of faults in the study area. Conversely, not all linear horizontal gradient magnitude ridges represent faults. They may correspond to topographic scarps or other linear geologic features, such as contacts at the eroded edges of tilted blocks, or dikes [31]. The horizontal gradient magnitude suggests that some faults have significant displacement at depth. The presence of linear horizontal gradient magnitude ridges that coincide in some places with the linear topographic scarp provides support for a tectonic origin [32]. The narrowness of the horizontal gradient magnitude ridges advocates near-surface and near-vertical boundaries for the magnetic sources [32]; their linearity supports a fault contact rather than a facies change [31]. As shown on the FVD map (Figure 4), the horizontal gradient magnitude also shows many magnetic lineaments interpreted as faults or magnetic intrusive bodies. The major lineaments trends are ENE-WSW and E-W though several lineaments follow WNW-ESE and N-S directions.

The [25] approach is also applied to the first vertical derivative (FVD) map to generate FVD peaks, which were stacked to the HGM peaks from Figure 6 and led to a unique map (Figure 7) displaying both the two sets of contact locations (FVD peaks in green and HGM peaks in red). Figure 7 is a comparative tool that enhances contact and lineaments locations. The effective location is obtained when FVD and HGM peaks coincide, if not, FVD provide the best location of lineaments. Hence, some of the lineaments highlighted by first vertical derivative method correlated very well with the assumed edges of the intrusive rocks or geological boundaries, and the other to important faults systems and faulted folds. The above maps enabled to draw magnetic lineaments and then provide a structural map of the study area.

\subsection{Lineaments and Integrated Structural Map}

Lineaments and spatial patterns of geophysical attributes are the most important information that can be obtained from magnetic interpretation. Steep features and straight faults are commonly expressed as subtle potential-field lineaments this expression can be gradient zones, alignments of separate local anomalies of various types and shapes, aligned breaks or discontinuities in the anomaly pattern, and so on [33]. Many large magnetic anomalies represent the ductile, ancient, healed basement structures obscuring the desirable subtle features [33]. Alignment of anomalies in geophysical maps provides crucial information for structural analysis. 


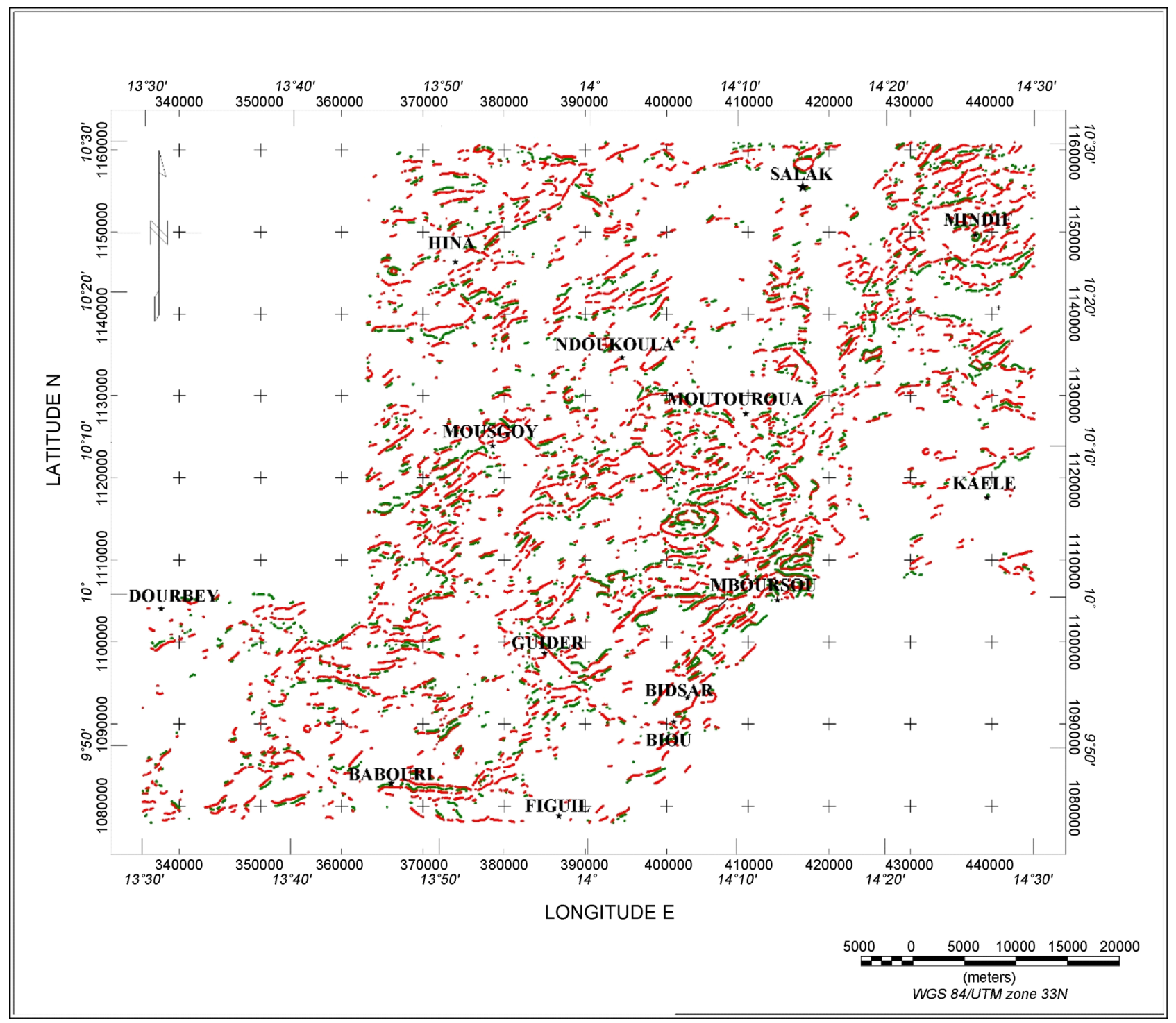

Figure 7. Resulted superposition peaks obtained from first vertical derivative (in green) and horizontal gradient magnitude (in red) map.

The results obtained were compared and integrated to construct the structural map shown in Figure 8. This map (Figure 8) shows shallow and deep-seated structures that are drown. Most of these structures were interpreted following the disruption and discontinuity of the magnetic signal from the FVD map, and considering the HGM and FVD peaks maps. Some of the lineaments were outlined through the visual inspection of the FVD map, while others were outlined by the alignment of points from the map of both FVD and HGM peaks. Accordingly, these lineaments might reveal top basement and intra-sediment structures. The overview of the interpreted structural map (Figure 8) shows that the lineaments outlined follow the NE-SW, NW-SE, ENE-WSW, NNE-SSW and WNW-ESE directions. The NE-SW, ENE-WSW and NW-SE trends are more strongly developed than the other identified trends. The highlighted lineaments are interpreted as faults, and dykes that may affect both the basement and the 


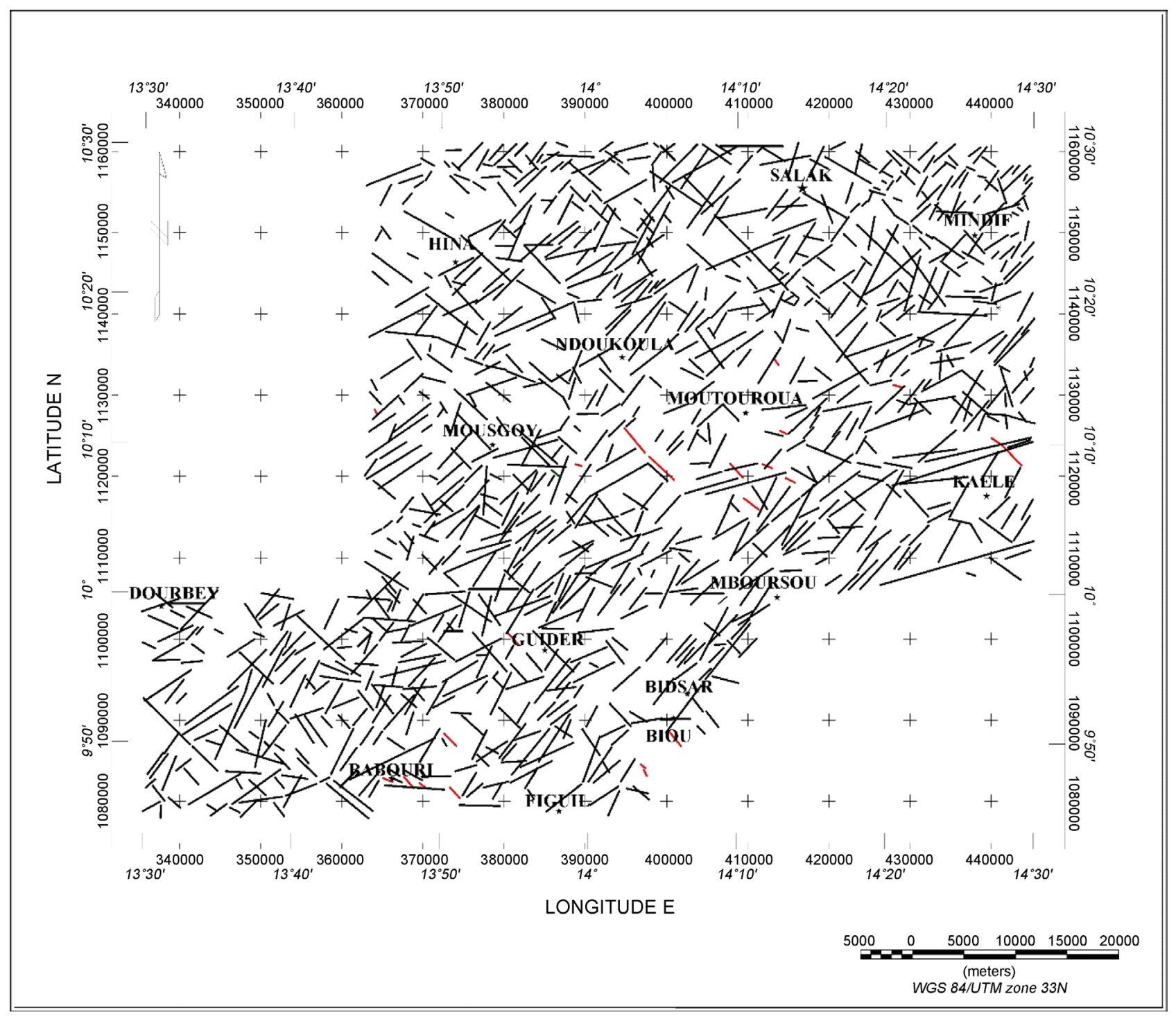

Figure 8. Integrated lineaments map with few inferred faults (in red).

Phanerozoic overburden, on one hand; on another hand, some of these lineaments may correspond to contacts between geological formations encountered over the area. Amongst the lineaments outlined, several are boundaries of probably sedimentary basins, as visible around the Mindif area.

The interpreted structural map (Figure 8) highlights the NE-SW and NW-SE regional trends, which control the subsurface structure beneath the study area. On the basis of the intensity range, character and shape of the magnetic gradient responses signaled on different maps (HGM and FVD maps), it appears clearly that they are essentially characterized by magnetic gradient high and low values on a moderate magnetic background (green to yellow) which correspond to the magnetic signature of the country rocks.

Since various directions are exhibited by faults, and probable dikes highlighted from the outputs of the magnetic products used for the current issue, we can easily state that, the study area recorded many stages of tectonic events. 
These tectonic events are associated to the putting in place of some folds and intrusive bodies into the Precambrian formations. The tectonic events have strongly aligned basement complex formations along a NE dominant direction.

\section{Discussion}

On the FVD map (Figure 4) and HGM map (Figure 5), there are abundant regional lineaments mostly striking NE and NW. Several lineaments were identified and interpreted as possible dykes or faults and contacts or boundaries between formations due to normal faulting along the same directions or more extensive NE-SW faulting. The highlighted system of lineaments (Figure 8) can be divided into major and minor lineaments. Their trends follow the NNE-SSW, ENE-WSW, and WNW-ESE, NE-SW, NW-SE, and N-S and E-W directions. Most of these directions correspond to the regional trends controlling the tectonic arrangement of the Pan African domain. And as shown by [34], at regional scale, these lineament trends suggest that region is intensively affected by the reactivated Pan-African shear zones and transcurrent faults. In addition, the above mentioned trends are generally referred to as Brasiliano/Pan-African trends and are associated with the Brasiliano/Pan-African orogeny [35]. According to [36], since the whole region displays a variety of rocks of various ages, it is therefore not surprising that the fracture network is related to different phases of tectonic activity.

The structural and tectonic analyses from aeromagnetic data indicate that the study area is intensively affected by faults, faulted folds, thrusts and dykes (Figure 8) following the directions mentioned above. Herein, some sets of faults and folds follow with predominant structural trends NW-SE and NE-SW directions, which are two major axis inherited from the different tectonic events occurred in whole region and affected the study area. At regional scale, these prominent trends constitute part of the regional configuration of the West and Central African rift system trending extensional basins taking up the strain caused by the NE to ENE oriented strike-slip motions emanating from the Gulf of Guinea [37] [38].

In the study area, there is a regional vertical NE-SW trending foliation with some locally disturbed zones, probably related to late E-W strike-slip faults. Part of structural features or lineaments underlined could be result from an early D1 deformation. This phase corresponds to the tangential, collusion tectonics [39] [40]. D1 phase is responsible of the nappe stacking that was emplaced horizontally to form a classical fold and thrust belt [41]. It has been shown that the resulted foliation was progressively transposed by D2 deformation phase. In the structural map displayed as synthesis of the geophysical lineaments (Figure 8), NW events broadly intersected NE events. Hence, they account or correlate to the D2 deformation phase which is characterized by the development of tight and upright folds [19]. The folds related to the D2 deformation event are witnessed at the whole area scale by [42], who state that these folds have antiformal and synformal structures with NE-SW axes. 
Additionally the highlighted lineaments follow the NNE-SSW, WNW-ESE and ENE-WSW trends. These outputs correlate those from [11]. According to [11], there are, including the NE-SW mainly pre-Tertiary extensional faults, normal synthetic tilted fault blocks, NNE-SSW antithetic normal faults associated with senestral wrenching, WNW-ESE normal faults. It is also observed ENE-WSW fault blocks associated with dextral transtensional movement of Borogo fault zone to the south, transpressional draped anticlines, transpressed basement blocks, with associated transtensional negative flower structures, and positive flower structures. The blending of these structural features is attributed to the importance of strike-slip deformation occurred in region, compared to the adjacent Central African Rift sub-System and West African Rift sub-System basins.

Geological studies claim the NE and NW structures being resulting from two deformations processes: the senestral shear followed by dextral shear; these occurred in the Pan African domain [18] [19] [43]. In addition, some lineaments highlighted by the study affect the basement; hence they could be the extensional effect of Godé-Gormaya shear zone (GGSZ). The N-S directed GGSZ is one of many generations of wrench zones in northern Cameroon cross-cutting earlier folds and foliation related to the thrusting and nappe refolding episodes [18].

At the regional scale, the prominent NE trend put in evidence by the present study is in conformity with the trend of Cameroon Shear Zone (CSZ). The NE and NW lineaments from the study suggest the deformations affecting the study area prevailed as at scale of the NW Cameroon domain within which it is found, since the NW Cameroon domain is located between two of four extensional domains developed between the main rigid continental lithospheric blocks [44]. As stated in [44], these domains are: 1) the Central African Rift System (CARS), extending from Sudan to the eastern part of the Benue Trough [45] and, 2) the West African Rift System (WARS), extending from the eastern part of the Benue Trough northward toward southern Libya [46]. In addition, [47] shown that the western central Africa rift system has suffered two rifting stages, namely during the Early Cretaceous, with NW-SE normal faulting, and during the Late Cretaceous, with NNW-SSE normal faulting associated with WNW-ESE left-lateral transcurrent fracturation. As resulted, these structural fabrics have played an important role in the formation of several geological structures and little sedimentary basins which took place during the late-orogenic shear zones, as reported by the current study.

\section{Conclusion}

In this work, two main analysis techniques were applied to aeromagnetic data to delineate the subsurface structures or to map the location of the magnetic source edges. The results revealed more prominent lineaments due to deep and shallow sources. The deep magnetic sources identified with the Phanerozoic sedimentary basement, while the shallow magnetic sources could be associated to near surface sources, probably magnetic rocks that intruded into the Phanerozoic sedi- 
mentary cover. The regional and local structures setting of the area are characterized by major faults and other structural elements mainly striking in the NESW, NW-SE, and E-W directions. Major magnetic lineaments trend in the NESW direction with minor ones trending in NW-SE, ENE-WSW, NNE-SSW, NNW-SSE and E-W direction. The NE-SW trend represents the dominant tectonic trend in the study area; it is in conformity with the trend of the Cameroon shear zone (CSZ). Several folds and faults discovered by the study have confirmed past studies (cite the authors of those studies) while others are inferred from the current investigation.

\section{Acknowledgements}

This work was carried out at the University of Yaoundé I, Cameroon, as part of first author's Ph.D. studies. The authors are thankful to Dr Meri-Liisa Airo for her valuable suggestions and the anonymous reviewers for their thorough comments which enabled to improve the initial version of this paper.

\section{References}

[1] Foulger, G.R. and Pierce, C. (2007) Geophysical Methods in Geology. Teaching Handbook, University of Durham, UK, 78 p.

[2] Xu, X.F., Deng, Y.Y. and He, Z.X. (2007) Application of Magnetic Directional Derivatives in Petroleum Geology Interpretation. EAGE 69 th Conference \& Exhibition, London, UK, 11-14 June 2007.

[3] Songfa L. and Tim, M. (1998) Using Images in a Geological Interpretation of Magnetic Data. AGSO Research Newsletter 28.

[4] Toteu, S.F., Van Schmus, R.W., Penaye, J. and Michard, A. (2001) New U-Pb and Sm-Nd Data from North-Central Cameroon and Its Bearing on the Pre-Pan-African History of Central Africa. Precambrian Research, 108, 45-73. https://doi.org/10.1016/S0301-9268(00)00149-2

[5] Tchameni, R., Pouclet, A., Penaye, J., Ganwa, A.A. and Toteu, S.F. (2006) Petrography and Geochemistry of the Ngaoundéré Pan-African Granitoids in Central Cameroon: Implications for Their Sources and Geological Setting. Journal of African Earth Sciences, 44, 511-529. https://doi.org/10.1016/j.jafrearsci.2005.11.017

[6] Paterson, Grant \& Watson Ltd. (1976) Études aéromagnétiques sur certaines régions de la République Unie du Cameroun. Rapport d'interprétation, Agence Canadienne de Développement International, Toronto, Canada, 192 p.

[7] Manga, S.C., Loule, J.P. and Koum, J.J. (2001) Tectonostratigraphic Evolution and Prospectivity of Logone Birni Basin, North-Cameroon-Central Africa. AAPG Extended Abstracts, 124.

[8] Njandjock, N.P., Manguelle-Dicoum, E., Ndougsa-Mbarga, T. and Tabod, C.T. (2006) Spectral Analysis and Gravity Modelling in Yagoua, Cameroon, Sedimentary Basin. Geofísica International, 45, 209-215.

[9] Poudjom Djomani, Y.H., Nnange, J.M., Diament, M., Ebinger, C.J. and Fairhead, J.D. (1995) Effective Elastic Thickness and Crustal Thickness Variations in West Central Africa Inferred from Gravity Data. Journal of Geophysical Research: Solid Earth, 100, 22047-22070. https://doi.org/10.1029/95JB01149

[10] Nguimbous-Kouoh, J.J., Ndougsa-Mbarga, T., Njandjock-Nouck, P., Eyike, A., Campos-Enriquez, J.O. and Manguelle-Dicoum, E. (2010) The Structure of the 
Goulfey-Tourba Sedimentary Basin (Chad-Cameroon): A Gravity Study. Geofisica Internacional, 49, 181-193.

[11] Loule, J.P. and Lumbomil, P. (2009) The Logone Birni Basin (LLB) in Northern Cameroon: Transition between the West African Rift Sub-System (WAS) and the Central African Rift Sub-System (CAS); Tectonic and Geophysical Models. Search and Discovery Article \#50171.

[12] Toteu, S.F., Penaye, J., Deloule, E., Van Schmus, W.R. and Tchameni, R. (2006) Diachronous Evolution of Volcano-Sedimentary Basins North of the Congo Craton: Insights from U-Pb Ion Microprobe Dating of Zircons from the Poli, Lom and Yaoundé Groups (Cameroon). Journal of African Earth Sciences, 44, 428-442. https://doi.org/10.1016/j.jafrearsci.2005.11.011

[13] Penaye, J., Kröner, A., Toteu, S.F., Van Schmus, W.R. and Doumnang, J.C. (2006) Evolution of the Mayo Kebbi Region as Revealed by Zircon Dating: An Early (ca. $740 \mathrm{Ma}$ ) Pan-African Magmatic Arc in Southwestern Chad. Journal of African Earth Sciences, 44, 530-542. https://doi.org/10.1016/j.jafrearsci.2005.11.018

[14] Toteu, S.F., Penaye, J. and Djomani, Y.P. (2004) Geodynamic Evolution of the Pan-African Belt in Central Africa with Special Reference to Cameroon. Canadian Journal of Earth Sciences, 41, 73-85. https://doi.org/10.1139/e03-079

[15] Van Schmus, W.R., Oliveira, E.P., Da Silva Filho, A.F., Toteu, S.F., Penaye, J. and Guimarães, I.P. (2008) Proterozoic Links between the Borborema Province, NE Brazil, and the Central African Fold Belt. In: Pankhurst, R.J., Trouw, R.A.J., de Brito Neves, B.B. and De Wit, M.J., Eds., West Gondwana. Pre-Cenozoic Correlations across the South Atlantic Region, Geological Society, London, Special Publication 294, 69-99. https://doi.org/10.1144/sp294.5

[16] Bouyo Houketchang, M., Toteu, S.F., Deloule, E., Penaye, J. and Van Schmus, W.R. (2009) U-Pb and Sm-Nd Dating of High-Pressure Granulites from Tcholliré and Banyo Regions: Evidence for a Pan-African Granulite Facies Metamorphism in North-Central Cameroon. Journal of African Earth Sciences, 54, 144-154. https://doi.org/10.1016/j.jafrearsci.2009.03.013

[17] Ngako, V., Affaton, P., Nnange, J.M. and Njanko, T. (2003) Pan-African Tectonic Evolution in Central and Southern Cameroon: Transpression and Transtension during Sinistral Shear Movements. Journal of African Earth Sciences, 36, 207-214. https://doi.org/10.1016/S0899-5362(03)00023-X

[18] Ngako, V., Affaton, P. and Njonfang, E. (2008) Pan-African Tectonics in Northwestern Cameroon Implication for the History of Western Gondwana. Gondwana Research, 14, 509-522. https://doi.org/10.1016/j.gr.2008.02.002

[19] Ngako, V. and Njonfang, E. (2011) Plates Amalgamation and Plate Destruction, the Western Gondwana History. In: Closson, D., Ed., Tectonics, InTech, UK, 3-34.

[20] Dawa1, D., Bouchez, J.-L., Paquette, J.-L. and Tchameni, R. (2013) The Pan-African Quartz-Syenite of Guider (North-Cameroon): Magnetic Fabric and U-Pb Dating of a Late-Orogenic Emplacement. Precambrian Research, 236, 132-144. https://doi.org/10.1016/j.precamres.2013.07.008

[21] Ndougsa-Mbarga, T., Feumoé, A.N., Manguelle-Dicoum, E. and Fairhead, J.D. (2012) Aeromagnetic Data Interpretation to Locate Buried Faults in South-East Cameroon. Geophysica, 48, 49-63.

[22] Feumoé, A.N., Ndougsa-Mbarga, T., Manguelle-Dicoum, E. and Fairhead, J.D. (2012) Delineation of Tectonic Lineaments Using Aeromagnetic Data for the SouthEast Cameroon area. Geofizika, 29, 33-50.

[23] Cordell, L. and Grauch, V.J.S. (1982) Mapping Basement Magnetization Zones from Aeromagnetic Data in the San Juan Basin, New Mexico. SEG Technical Program 
Expanded Abstracts, 246-247. https://doi.org/10.1190/1.1826915

[24] Cordell, L. and Grauch, V.J.S. (1985) Mapping Basement Magnetization Zones from Aeromagnetic Data in the San Juan Basin, New Mexico. In: Hinze, W.J., Ed., The Utility of Regional Gravity and Magnetic Anomaly Maps, Society of Exploration Geophysicists, 181-197. https://doi.org/10.1190/1.0931830346.ch16

[25] Blakely, R.J. and Simpson, R.W. (1986) Approximating Edges of Source Bodies from Magnetic or Gravity Anomalies. Geophysics, 51, 1494-1498. https://doi.org/10.1190/1.1442197

[26] Cooper, G.R.J. (1997) GravMap and PFproc: Software for Filtering Geophysical Map Data. Computers \& Geosciences, 23, 91-101. https://doi.org/10.1016/s0098-3004(96)00064-7

[27] Gunn, P.J. (1975) Linear Transformation of Gravity and Magnetic Fields. Geophysical Prospecting, 23, 300-312. https://doi.org/10.1111/j.1365-2478.1975.tb01530.x

[28] Phillips, J.D. (2000) Locating Magnetic Contacts: A Comparison of the Horizontal Gradient, Analytic Signal, and Local Wavenumber Methods: Society of Exploration Geophysicists. Abstracts with Programs, Calgary, 2000.

[29] Li, J. and Morozov, I. (2004) Continuous Equivalent Source Surface Approach for Accurate Interpolation and Continuation. 2004 CSEG, Calgary.

[30] Pilkington, M. and Roest, W.R. (1992) Draping Aeromagnetic Data in Areas of Rugged Topography. Journal of Applied Geophysics, 29, 135-142. https://doi.org/10.1016/0926-9851(92)90004-5

[31] Grauch, V.J.S. and Ruleman, C.A. (2013) Identifying Buried Segments of Active Faults in the Northern Rio Grande Rift Using Aeromagnetic, LiDAR, and Gravity Data, South-Central Colorado, USA. International Journal of Geophysics, 2013, Article: ID 804216.

[32] Phillips, J.D., Hansen, R.O. and Blakely, R.J. (2007) The Use of Curvature in Potential-Field Interpretation. Exploration Geophysics, 38, 111-119. https://doi.org/10.1071/EG07014

[33] Henry, L., Dinu, P., Reg, O. and Lorraine, G. (2003) Mapping of Basement Faults with Gravity and Magnetic Data in Northern Alberta. 12 p.

[34] Raimi, J., Dewu, B.B.M. and Sule, P. (2014) Existence of a Possible Subsurface Ring Complex in the Northwestern Part of the Nigerian Younger Granite Province: A Contribution from Aeromagnetic and Remote Sensing Data.

[35] Goodluck, K.A., Randell, A.S. and David, I.M.M. (2014) Using High-Resolution Aeromagnetic Data to Recognise and Map Intra-Sedimentary Volcanic Rocks and Geological Structures across the Cretaceous Middle Benue Trough, Nigeria. Journal of African Earth Sciences, 99, 625-636. https://doi.org/10.1016/j.jafrearsci.2014.02.017

[36] Vignes-Adler, M., Le Page, A. and Adler, P.M. (1991) Fractal Analysis of Fracturing in Two African Regions, from Satellite Imagery to Ground Scale. Tectonophysics, 196, 69-86. https://doi.org/10.1016/0040-1951(91)90290-9

[37] Fairhead, J.D. and Okereke, C.S. (1987) A Regional Study of the West African Rift System in Nigeria and Cameroon and Its Tectonic Interpretation. Tectonophysics, 143, 141-159. https://doi.org/10.1016/0040-1951(87)90084-9

[38] Eyike, A., Werner, S.C., Ebbing, J. and Dicoum, E.M. (2010) On the Use of Global Potential Field Models for Regional Interpretation of the West and Central African Rift system. Tectonophysics, 492, 25-39. https://doi.org/10.1016/j.tecto.2010.04.026

[39] Rolin P. (1995) La zone de décrochements panafricains des Oubanguides en République Centrafricaine. Comptes Rendus de I Académie des Sciences (Paris), 
320, 63-69.

[40] Rolin P. (1998) Nouvelles données tectoniques sur le Précambrien en Centrafrique, implication géodynamique. Ed. Collect. Géocam.1/1998. Presse Univ.Yaoundé I P. 240, 224.

[41] Burg, J.P., Corsini, M., Diop, C. and Maurin, J.C. (1993) Structure et cinématique du Sud de la chaîne des Mauritanides: Un système de nappe tégumentaire varisque. Comptes Rendus de 1 Académie des Sciences, 317, 697-703.

[42] Ganno, S., Nzenti, J.P., Ngnotue, T., Kankeu, B. and Kouankap, N.G.D. (2010) Polyphase Deformation and Evidence for Transpressive Tectonics in the Kimbi Area, Northwestern Cameroon Pan-African Fold Belt. Journal of Geology and Mining Research, 2, 001-015.

[43] Njanko, T., Nédélec, A., Kwékam, M., Siqueira, R. and Esteban, L. (2010) Emplacement and Deformation of the Fomopéa Pluton: Implication for the Pan-African History of Western Cameroon. Journal of Structural Geology, 32, 306-320. https://doi.org/10.1016/j.jsg.2009.12.007

[44] Heine, C., Zoethout, J. and Müller, R.D. (2013) Kinematics of the South Atlantic rift. Solid Earth, 4, 215-253. https://doi.org/10.5194/se-4-215-2013

[45] Fairhead, J.D. (1986) Geophysical Controls on Sedimentation within the African Rift Systems. In: Frostick, L., et al., Eds., Sedimentation in the African Rifts, Geological Society of London Special Publication 25, 19-27.

https://doi.org/10.1144/gsl.sp.1986.025.01.03

[46] Genik, G.J. (1992) Regional Framework, Structural and Petroleum Aspects of Rift Basins in Niger, Chad and the Central African Republic (C.A.R.). Tectonophysics, 213, 169-185. https://doi.org/10.1016/0040-1951(92)90257-7

[47] Maurin, J.C. and Guiraud, R. (1993) Basement Control in the Development of the Early Cretaceous West and Central African Rift System. Tectonophysics, 228, 8195. https://doi.org/10.1016/0040-1951(93)90215-6

\section{Scientific Research Publishing}

Submit or recommend next manuscript to SCIRP and we will provide best service for you:

Accepting pre-submission inquiries through Email, Facebook, LinkedIn, Twitter, etc. A wide selection of journals (inclusive of 9 subjects, more than 200 journals)

Providing 24-hour high-quality service

User-friendly online submission system

Fair and swift peer-review system

Efficient typesetting and proofreading procedure

Display of the result of downloads and visits, as well as the number of cited articles

Maximum dissemination of your research work

Submit your manuscript at: http://papersubmission.scirp.org/

Or contact ijg@scirp.org 